\title{
Reflections on Clinical Reasoning in Gestalt Therapy
}

\author{
Adelma do Socorro Gonçalves Pimentel1', Kamilly Souza Vale², \\ Lorena Schalken de Andrade'2, Márcia Nami Endo Souza², Mylena Nahum Sousa Cardoso² \\ ${ }^{1}$ Graduate Program in Psychology, Federal University of Pará, Pará, Brazil \\ ${ }^{2}$ Psycholgy Faculty, Federal University of Pará, Pará, Brazil \\ Email: adelmapi@ufpa.br, k.millyvale@gmail.com, lorenaschalken@gmail.com, endo_souza@hotmail.com, \\ mylenanahum@gmail.com
}

Received 17 November 2015; accepted 23 January 2016; published 26 January 2016

Copyright (C) 2016 by authors and Scientific Research Publishing Inc.

This work is licensed under the Creative Commons Attribution International License (CC BY).

http://creativecommons.org/licenses/by/4.0/

(c) (7) Open Access

\begin{abstract}
Using articles on psychotherapeutic management in Geltast Therapy published in Brazil between 2005 and 2015 as a basis, an academic literature search was performed from the Scielo data base in the Pesic site. We obtained a brief result containing 46 articles whose vast majority emphasized current clinical practices; even though, some articles indicate a propensity for rupture of this restricted tendency in favor of an integrating perspective, seeing the individual as a whole, in order to facilitate the autonomy expansion of public service users of clinical psychology. It was also observed that, for the past five years, there has been an increase in scientific production focused on clinical procedures that envisaged public policies which contributed for the renovation of the semantic field. We concluded by stressing the importance of development of research in the area of psychotherapeutic process, based on a more ecological dimension before the world.
\end{abstract}

\section{Keywords}

Gestalt Therapy, Epistemology, Clinical Psychology, Management

\section{Introduction}

The semantic field ${ }^{1}$ where the concept of clinic therapeutic reasoning falls is the clinical method that comprises psychodiagnosis, relational ethics, the client-therapist contract, the physical space, the time dedicated to questions presented by the dialogue participants, therapeutic alliance, etc. It also covers computer and communica-

${ }^{1}$ Language structures that organizes a terminology used by professionals of a same area of health. Carvalho EC, Cruz DALM, Herdman TH. Contribution of standardized language for the production of knowledge, clinical reasoning, and nursing clinical practice. Rev Bras Enferm. 2013; 66(esp): 134-141. 
tion technology, considering that the Internet opens the possibility of online psychotherapy.

According to (Ribeiro, 2010), "Online psychotherapy is a new means of doing psychotherapy; the therapist is in a different location form that of the patient, which means that bidirectional communication, is limited to the audio, audiovisual and text apparatus available for distance communication. Thus, 'cybernetic therapist' assimilates to a 'blind therapist' who, unable to count on the usual visual resources, the implicit 'warmth' of personal contact to the on-site therapeutic scenery, focuses his/her attention to the form and content of the messages that comes to him/her, also pointing the non-verbal contents found in the communication and pertaining to other sensibilities" (pp. 61-62).

Thus, the reflections on clinical reasoning in Gestalt Therapy on this text are in conformity with a proposal to think about listening and facilitation of experience (Mesquita, 2011). Thereby, we made an academic literature search from the perspectives that clinical procedures have been elaborated by professionals in the traditional way (private), expanded clinic, ecological etc. to identify and analyze such styles. For this purpose, we consolidated a survey of scientific papers published between 2005 and 2015, in the Scientific Electronic Library Online (SCIELO) site.

Gestalt Therapy is incorporated in the humanistic psychotherapy approach being part of the so-called "third power" of psychological approaches that emerged in the 1950s, where the psychological subject was formed and characterized by autonomy and reflexivity (Giddens, 2002). Based on a different proposal of psychotherapeutic practices in use at the time, the theory initially thought by Fritz Perls presented as innovative for the period: the notions of field and motivation (Kohler, 1963; Ribeiro, 2010; Nascimento \& Vale, 2013).

Perls (2002) defined field as the configuration that each individual organizes one's pace of life, and that places him/her in contact with the other promoting the establishment of the relations, and of the process of attributing meanings to the phenomena that surge in the intentional consciousness. The inter-relation that occurs in the field permits its construction and modification as a whole (Ribeiro, 2006).

In the 21st century, qualitative research performed in graduate programs, private institutions and psychologist associations has contributed for the theoretical and methodological updating of the Gestalt system. In the reconceptualization of some concepts, the following contributions are articulated; from the epistemology of complexity and the intersectionality in clinical interventions. In this group, the concept of subjectivity updates the concept of anthropological approach of the concept of organism. The evaluation of the processes of subjectivitation is a demand of post-modern clinical procedures (Pimentel, 2011, 2012).

Thereby, clinical procedure stops organizing psychological appointments in the classical therapy only, accepting the fact that it is not to private clinical practice. Psychological emergency attendance, advising, short or long term focal psychotherapy, on-line psychotherapy, and existential groups are some forms of Gestalt-therapists that may perform clinical practices, and that require specific psychotherapeutic management. The tension among visual, audition and motivational perceptions is elements of field received by the psychotherapist through the figure/ground polarity (Kohler, 1963).

According to Robine (2015), "Our responsibility as therapists is very important when choosing the words and representations that we manage during the relation, in the choice of the logic which, although implicit, that organizes our thoughts and responses" (p. 118).

The various performance modalities include the expansion of the contact boundaries, awareness, self-acknowledgements of the psychotherapist through one's personal development. Resulting from updates that occur during clinical procedures and in the psychologist himself/herself a therapeutic Project is under construction structured in points of view of a social and politically engaged clinical procedure, understood as a place of experimentation of procedures, bonds, dialogue and interrelations (Alvim \& Castro, 2015; Robine, 2015). For Corey $(2009)^{2}$ "Confrontation is a part of the client-therapist relationship in the Gestalt framework. Yontef advocates for an "empathic inquiry" focused on awareness when this method is used" (p. 215).

Creativity is an imperative dimension for the development of clinical procedure management, however in order to promote health care, the action anchoring of the psychotherapist requires focusing on the client's experience, since in the existential phenomenological horizon, such experience becomes a starting and arrival point to the therapeutic project. Art and creativity are opportunities to develop novel concepts out of one's own sense of daring (Zinker, 1977) ${ }^{3}$. As a result, Gestalt-therapists will consolidate the clinic ethical agency.

Equally, to think about clinic in the contemporaneity means dissociation from the predominant biomedical

${ }^{2}$ Corey, G. (2009). Theory and practice of counseling and psychotherapy (8th ed.).

${ }^{3}$ Zinker, J. (1977). Creative Process in Gestalt Therapy. New York, NY: Random House Publishing. 
logic that limits psychotherapeutic practice, from an individual, solipsist focus and directed only toward pathological analyses. Clinical reasoning that takes into consideration the social, the political, the difference, and the diversity may get close to more sensitive aspects of human condition. The unfolding of this therapeutic process will typically involve a range of expressive techniques and creative experiments developed collaboratively between therapist and client (Alvim \& Castro, 2015; Robine, 2015; Pimentel, 2011, www.counselling-directory.org.uk/gestalt-therapy.html).

According to e Goldman (1991 apud Ribeiro \& Leal, 1996: p. 591) "Clinical Reasoning is based on experience and learning, inductive and deductive reasoning, interpretation, complaint analysis, personal history, observation; diagnosis, data integration and process of help by discussing with the client (or patient) the therapeutic plan".

\section{Methodology}

We have a done an academic literature review on modes of clinical reasoning in Gestalt-therapy on the Pepsic site, Scielo database to identify articles published in Brazil between 2005 and 2015. We made searches using the following keywords: Gestalt-therapy and psychotherapeutic management, Gestalt-therapy and clinic and Gestalt-therapy. As a result, we found 46 texts. As for the criteria of inclusion we defined: a) texts that analyzed psychotherapeutic clinical reasoning; b) approached areas of traditional clinical procedures; c) reports of researches on the clinical method. The criteria of exclusion were: a) articles published before 2005; b) research of strictly philosophical nature without articulation with clinical practices. After a meticulous reading of the abstracts, we selected 13 articles according to criteria of inclusion. The analyses emphasized themes following guidance for qualitative research (Gil, 2008; Minayo, 1992).

\section{Results and Discussions}

The articles focused group psychotherapy, the method of the experiment, the dreams, the modes of use of the technique, gestalt-therapist training, clinic, ludotherapy, assistance to psychotics and method updating (Table 1).

Carvalho and Costa (2010) presented a phenomenological vision of psychopathology in Gestalt-therapy, and of the subject in the Psychotic adjustment. They emphasized the limitation of the theoretical referential and the psychotherapeutic practices. They evaluate the conception of health and disease and suggest approaching them as a dialectic process.

\begin{tabular}{|c|c|c|}
\hline Periodic & Subject & Year of issuance \\
\hline Revista da Abordagem Gestáltica & History of group psychotherapy & 2014 \\
\hline Revista NUFEN & Dreams as experiment & 2014 \\
\hline Revista da Abordagem Gestáltica & Ethics and gestalt-therapy & 2013 \\
\hline Revista da Abordagem Gestáltica & Learning process in the academic environment & 2012 \\
\hline Revista da Abordagem Gestáltica & Clinical procedure as poietic & 2012 \\
\hline Revista da Abordagem Gestáltica & The here and now in the gestalt-therapy & 2011 \\
\hline Revista da Abordagem Gestáltica & Lucid activities in infant care & 2010 \\
\hline Revista da Abordagem Gestáltica & Play activity and gestalt-therapy & 2011 \\
\hline Revista da Abordagem Gestáltica & Psychotic adjustments & 2010 \\
\hline Revista da Abordagem Gestáltica & Therapeutic relation & 2009 \\
\hline Estudos e Pesquisas em Psicologia & Psychopathology in infancy & 2009 \\
\hline Estudos e Pesquisas em Psicologia & Therapeutic groups in communities & 2009 \\
\hline Estudos e Pesquisas em Psicologia & Work with experience in gestalt-therapy & 2005 \\
\hline Estudos e Pesquisas em Psicologia & Gestalt-therapy and post-modernity & 2005 \\
\hline
\end{tabular}

Source: PEPSIC database. 
Freitas (2009) considered the relation between the psychotherapist and the patient and their meeting. He supports his meditations on the concept of understanding "the other" of Merleau-Ponty. He also pointed questions relating to the relations and the communication between the psychotherapist and client during the appointment.

Tavares and Andrade (2009) contemplated the clinical hearing of the psychologist relating it to possible impacts and conflicts in the psychotherapeutic management caused by religious beliefs. They claimed that the two may jeopardize the phenomenological listening. Their article shows reports of cases. Silva and Arrelias (2010), they conjectured the provision of care for two children in process of ludotherapy, as well as the relation psychotherapist-client. The cases reported the difficulty the children had to communicate with their families. The authors provided orientation assistance to their families and guardians in order to facilitate the psychological nutrition and a reconfiguration of the interpersonal relations. The article highlighted the importance that the psychotherapist who works with infant care, should enjoy playing, and likes children, that he/she inspires confidence to caregivers during the psychotherapeutic management.

Rodrigues and Nunes (2010), on work with children gave some important contributions for the ludotherapist training: philosophical bases of Gestalt-Therapy, the dialogic relation, the contact, to play with the use of games, dummies, clay and scrap. They reported difficulties faced in the interaction with the children's parents during the therapeutic process, and that they are not always available to collaborate.

Campos, Toledo and Faria (2011), reported their experience with a group of children in public health care, aiming through means of lucid activities and expanded clinic to offer proper care to the children in order to benefit the appropriation of their potentialities. Cardoso (2009) reported an experience with therapeutic groups assisted by an extension program, provided for patients with diabetes and suffering from hypertension in the Programa Saúde da Família (Family Health Program). The methodology consisted of individual appointments, home visits, group psychotherapy, and therapeutic groups, among others. The groups aimed the promotion of a comfortable environment for the free expression of the participants in relation to the proposed subject that surged from the demands of the group. Expressive resources, such as collages were also used to make it easier the demonstration of the participants' experience.

Boris (2014) revised the bases for clinical procedures in group: the contribution of psychoanalysis, psycho drama, Zen-Buddhism, phenomenology and existentialism. Besides, it brought the expanded clinic point of view in the group psychotherapeutic management, through various dynamic strategies. Due to big demand in basic care volume, the work with groups contributes to the expansion of benefits from clinical practices to the community being assisted in the service unit. According to Ayres (2004: p. 89), "it is necessary to overcome the individualistic conformation, toward collective, institutional and structural spheres of intervention and enrich the biomedical rationality with constructs from other sciences and other knowledge”.

Figueiredo and Castro (2015) criticized the small volume of studies on clinical reasoning and psychotherapeutic management. They outlined the work of psychologists with subjects with hypertension highlighting the biopsychosocial aspects involved in the activation and maintenance of hypertension. They state that Gestalt understanding helps to learn about the disease in its totality and in expressions of their experiences lived in the relational context. The phenomenological conception of the health-disease process and the transdisciplinary performance of the staff provide full health care.

Silva and Boaventura (2011) suggest a reflection on the contributions of Gestalt-therapy during psychological sessions with patients with cancer. In a context where the subject is found in a process of vulnerability, the professional's skill is very important to provide a better quality of life to users. The authors highlight that intervention during clinical procedures are intended to widen the contact with one's feelings to allow users to obtain self-support to face the illness.

Ferreira (2009) analyzed, through semi-structured interview and observations, behaviors that are repeated within love relationships. The investigation used as support the Self-Theory, and Intersubjectivity, Dialogic Approach, and Gestalt-Therapy. Based on analyzes of the interviews, it was confirmed the existence of repetitive behavior in the relations and difficulty to find existential solutions. Thereby, Psychotherapy helps the subjects to recognize the existence of barriers, opening way for healthier methods to be with oneself and other people.

Santana and Yano (2014) discuss how work with dreams Gestalt-Therapy can be used in the therapeutic setting. Through a descriptive methodology, the authors reveal how this form of management proportionate integration of the patient. They also remind the importance of the Psychotherapist's continuous training: personal, theoretical, and methodological to be able to properly assist his/her patients. On the use of experiments during the psychotherapeutic management, Alvim and Ribeiro (2009) stress that they go beyond the use of techniques 
and are based in the phenomenology of experience. The authors dialogue with Merleau-Ponty to give rise to new forms of thinking in the activity.

Alvim (2012) presents clinical procedure as poietic a proposal of intervention addressed to the search for new meanings to the lived/experience. They remind that it is very important that psychotherapeutic management distances itself from psychologizant practice, and understand it as the constructed part of the relation between two parties. This proposition is compatible with the proposal made by Robine (2005) on articulation between practice, the theory of field and the emergency of new subjects in post-modernity. Finally, Nascimento and Vale (2013) explained the ethical importance as a basic point in clinical reasoning and psychotherapeutic management in Gestalt-therapy. The Ethics learned by psychologists as anthological principle, critical reflection of supports for a contemporaneous practice in any social context.

\section{Final Considerations}

Gestaltic therapy organizes a psychotherapeutic process based on the "Here-Now" "Organismic Self-Regulation”, "Holistic Relational Field”, "Contact”, "Self” and "Boundaries of Contact”, designed to facilitate the creative experience and awareness. The interventions in this approach occur from the perception of sense and the meaning attributed by the client to the existential events, "As our awareness is heightened, we develop a deeper understanding of ourselves, and how we function in the world".

(www.counsellingsouth.com.au/articles/gestalt-therapy/)

Based on the data we obtained, we observed, during the last five years, an increase in scientific production focused on therapy that envisaged public policies with publications in the areas of: Basic Health Care (Carvalho, Bosi, \& Freire, 2009), Psycho-Oncology (Silva \& Boaventura, 2011), Group Psychotherapy (Boris, 2014), Collective Health Care and Drug Addiction (Tessaro \& Ratto, 2015), among others, what permits new modes of clinical reasoning and psychotherapeutic management in Gestalt-therapy.

\section{References}

Alvim, M. B. (2012). A clínica como poiética. Estudos e Pesquisas em Psicologia, Rio de Janeiro, 12, 1007-1023. http://dx.doi.org/10.12957/epp.2012.8234

Alvim, M. B., \& Castro, F. G. (2015). O que define uma clínica de situações contemporâneas? Apontamentos a partir de J. P. Sartre e M. Merleau-Ponty. In: Alvim, M. B. (Org.), Clínica de situações contemporâneas: Fenomenologia e interdisciplinariedade. Curitiba: Ed. Juruá.

Alvim, M. B., \& Ribeiro, J. P. (2009). O lugar da experimentação no trabalho clínico em Gestalt-terapia. Estudos e Pesquisas em Psicologia, 9, 37-58.

Ayres, J. R. C. M. (2004). Cuidado e reconstrução das práticas de saúde. Interface-Comunication, Saúde, Educ., São Paulo, 8, 73-92. http://dx.doi.org/10.1590/S1414-32832004000100005

Boris, G. D. J. B. (2014). Elementos para uma história da psicoterapia de grupo. Revista da Abordagem Gestáltica, Campinas, 20, 206-212.

Campos, B. G., Toledo, T. B., \& Faria, N. J. (2011) Clínica Gestáltica Infantil e integralidade em uma Unidade Básica de Saúde. Revista da Abordagem Gestáltica, Campinas, 17, 23-29.

Cardoso, C. L. (2009). Grupos terapêuticos na abordagem Gestáltica: Uma proposta de atuação clinica em comunidades. Estudos e Pesquisas em Psicologia, Rio de Janeiro, 9, 122-136. http://dx.doi.org/10.12957/epp.2009.9139

Carvalho, L. B., Bosi, M. L. M., \& Freire, J. C. (2009). A Prática do Psicólogo em Saúde Coletiva: Um Estudo no Município de Fortaleza (CE), Brasil. Psicologia Ciência e Profissão, Brasília, 29, 60-73.

http://dx.doi.org/10.1590/S1414-98932009000100006

Carvalho, L. C., \& Costa, I. I. (2010). A clínica gestáltica e os ajustamentos do tipo psicótico. Revista da Abordagem Gestáltica, Campinas, 16, 12-18.

Ferreira, T. B. M. (2009). Implicações dos comportamentos repetitivos no contexto das relações amorosas. Revista da Abordagem Gestáltica, 15, 30-35.

Figueiredo, J. de O., \& Castro, E. E. C. (2015). Ajustamento criativo e estresse na hipertensão arterial sistêmica. Revista da Abordagem Gestáltica, Campinas, 21, 37-46.

Freitas, J. de L. (2009). Reflexões sobre a relação psicoterapêutica: diÁlogos com Merleau Ponty. Revista da Abordagem Gestáltica, Campinas, 15, 103-107.

Giddens, A. (2002). Modernidade e identidade. Rio de Janeiro: Zahar Ed. 
Gil, A. C. (2008). Como elaborar projetos de pesquisa (4th ed.). São Paulo: Atlas.

Mesquita, G. R. (2011). O Aqui-e-agora na Gestalt-Terapia: Um Diálogo com a sociologia da contemporaneidade. Revista da Abordagem Gestáltica, Goiânia, 17, 59-67.

Minayo, M. C. de S. (1992). O desafio do conhecimento: pesquisa qualitativa em saúde (10th ed.). São Paulo: HUCITEC.

Nascimento, L. C. S., \& Vale, K. S. (2013). Reflexões acerca do fazer ético na clínica gestáltica: Um estudo exploratório. Revista da Abordagem gestáltica, Goiânia, 19, 157-166.

Perls, F. S. (2002). Ego, fome e Agressão. São Paulo: Summus.

Pimentel, A. (2012). Psicoterapia e clínica ampliada: Diferenciando horizontes interventivos. In A. F. Holanda (Ed.), O campo das psicoterapias: Reflexões atuais. Curitiba: Juruá.

Pimentel, A. (2011). Violência Psicológica Conjugal: Pesquisa e Intervenção. São Paulo: Summus.

Ribeiro, J. P. (2006). Vade Mecum de Gestalt Terapia: Conceitos básicos. São Paulo: Summus.

Ribeiro, J. P., \& Leal, I. P. (1996). Psicologia clínica da saúde. Análise Psicológica, 4, 589-599.

Ribeiro, M. M. C. (2010). O setting como fator terapêutico na prática clínica: Construção e validação de um instrumento de avaliação do manejo do setting. Tese (Doutorado em Ciências Biomédicas), Portugal: Instituto de Ciências Biomédicas Abel Salazar, Universidade do Porto, $248 \mathrm{f}$.

Robine, J. M. (2005). A Gestalt-Terapia terá a ousadia de desenvolver seu paradigma pós-moderno? Estudos e Pesquisas em Psicologia, 5, 102-126.

Robine, J. M. (2015). A Mudança Social começa a dois e Implicações Sociais da Gestal-terapia. In M. B. Alvim (Org), Clínica de situações contemporâneas: Fenomenologia e interdisciplinariedade. Curitiba: Ed. Juruá.

Rodrigues, P., \& Nunes, A. L. (2010). Brincar: Um Olhar Gestáltico. Revista da Abordagem Gestáltica, 16, 189-198.

Santana, D. D., \& Yano, L. P. (2014). Experimentos Em Gestalt-Terapia: Os Sonhos Como Recurso Integrativo. Revista NUFEN, 6, 91-101.

Silva, R. B., \& Boaventura, C. B. F. (2011). Psico-oncologia e Gestalt-terapia: Uma comunicação possível e necessária. Revista da Abordagem Gestáltica, 17, 37-46.

Silva, C., \& Arrelias, L. (2010). Ludoterapia gestáltica: Dois casos clínicos. Revista NUFEN, 2, 51-65.

Tavares, J. P., \& Andrade, C. C. (2009). A escuta fenomenológica comprometida pela ótica religiosa de uma gestalt terapeuta. Revista da Abordagem Gestáltica, 15, 21-29.

Tessaro, L.G. S., \& Ratto, C. G. (2015). Pessoas que dependem de drogas: ensaio de figuras e fechamentos. Revista da Abordagem Gestáltica, 21, 83-94. 